\section{Charges da Copa na Rússia}

\section{Duke}

A seção Poética, dedicada às múltiplas possibilidades das abordagens artísticas do futebol e do mundo dos esportes, reúne nesta edição a série composta de 34 charges do artista belo-horizontino Eduardo dos Reis Evangelista, o Duke, publicadas origi-

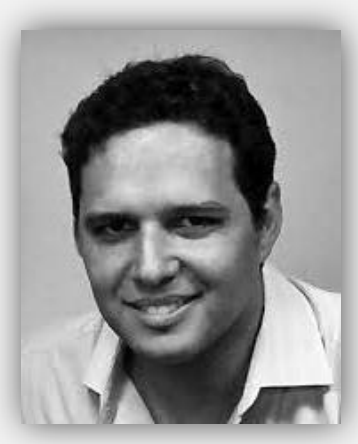
nalmente no caderno especial "Copa 2018”, do jornal $O$ Tempo, de Belo Horizonte/MG, no período de 14 de junho a 16 de julho de 2018, ao longo da Copa do Mundo da Rússia.

Geralmente, seus desenhos são apresentados em um único quadro, que ora dramatiza uma ação, condensando alguns elementos, ora encena um breve diálogo, revelando-nos chistes sofisticadíssimos.
Nesta série, como poucos, o chargista evidencia mais uma vez sua tamanha capacidade de relacionar futebol, política e humor. De maneira sempre sagaz, Duke leva aos seus leitores/seguidores um modo divertido, irônico e reflexivo de enxergar o mundo da bola, pois suas charges são, antes de tudo, um instrumento de reflexão política.

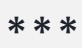

Duke é o pseudônimo de Eduardo dos Reis Evangelista, nascido em Belo Horizonte/MG, em 1973. Formou-se em Cinema da Animação pela Escola de Belas Artes da UFMG. Publicou, dentre outros livros, Só futebol 2011, Só futebol 2012, Só futebol 2013, todos subintitulados 0 futebol mineiro e brasileiro nas charges do Duke. 0 artista recebeu muitas menções em salões de humor e importantes premiações. Atualmente, é chargista diário do jornal $O$ Tempo. 
SUA PRESENCA NOS AGORA FIQUEI ESTÁDIOS DURANTE OS JOGOS FOI VETADA!!!

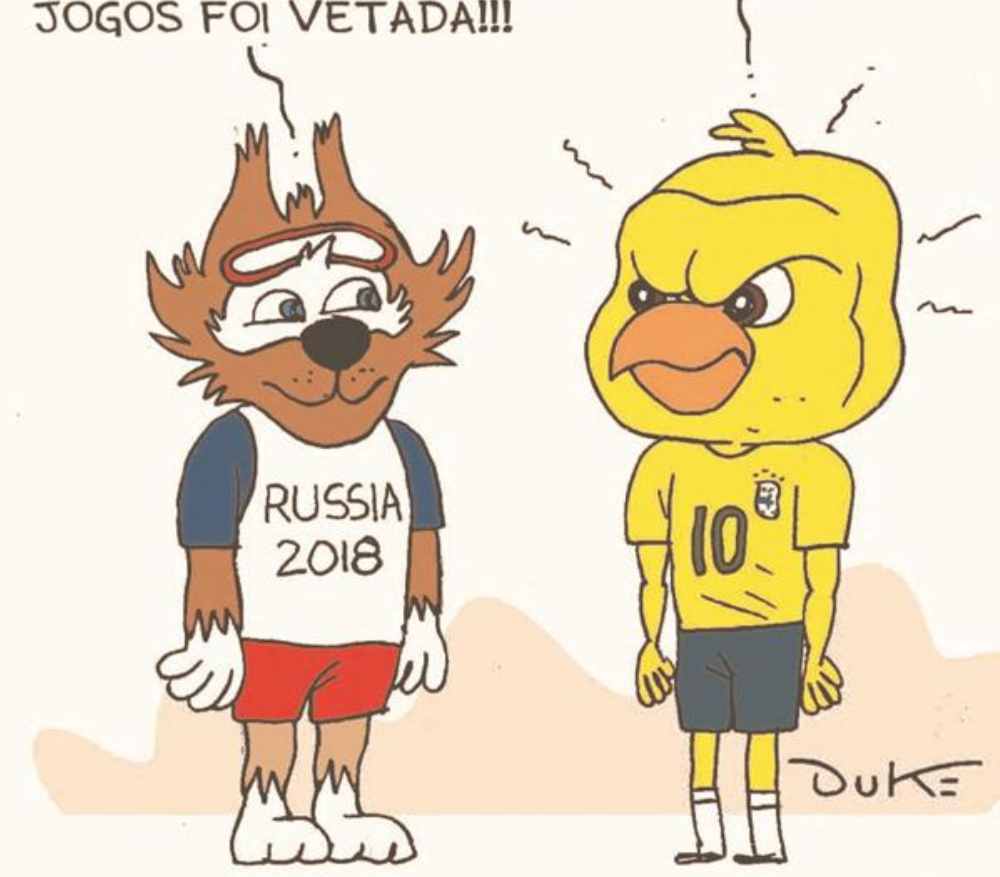




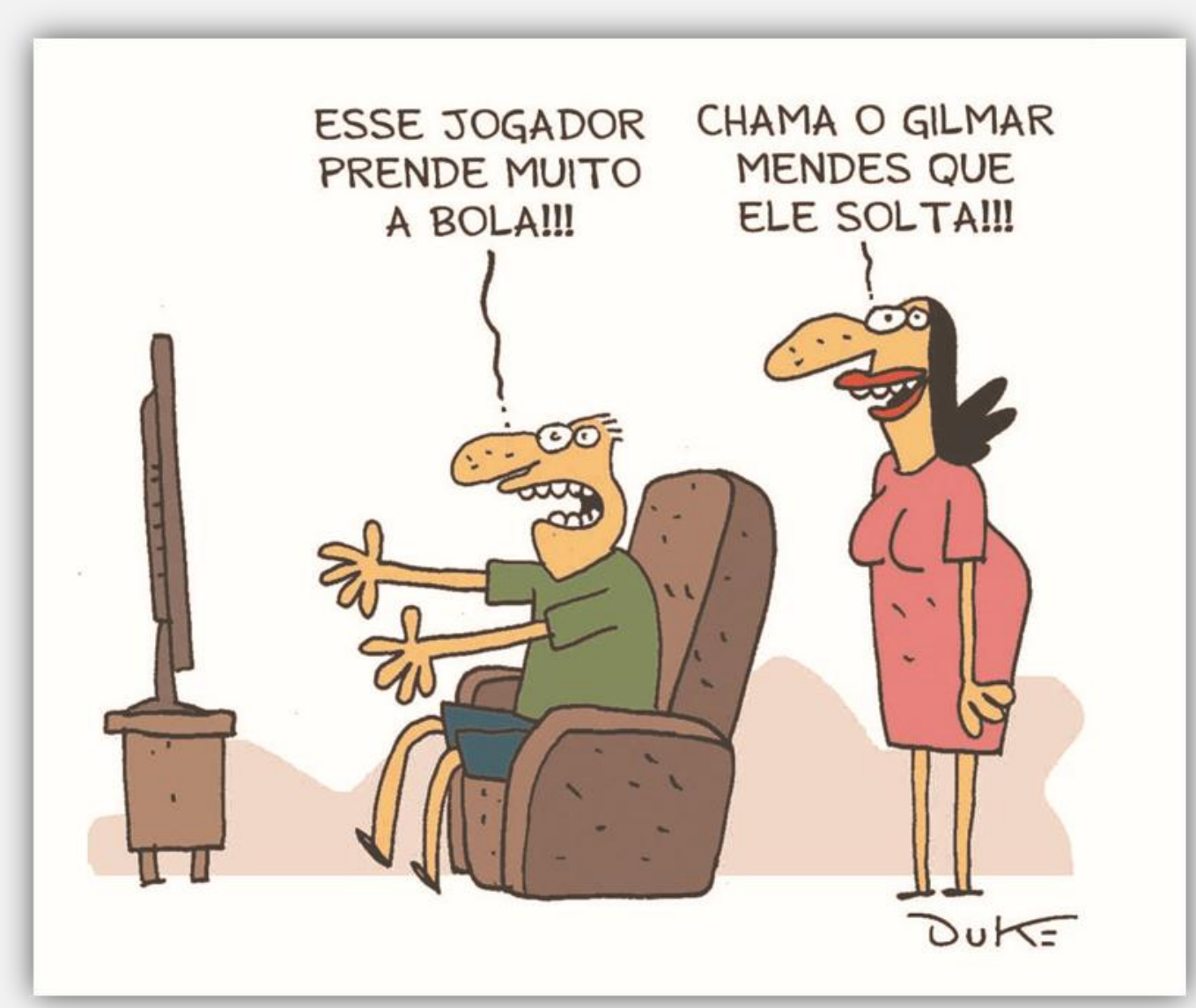




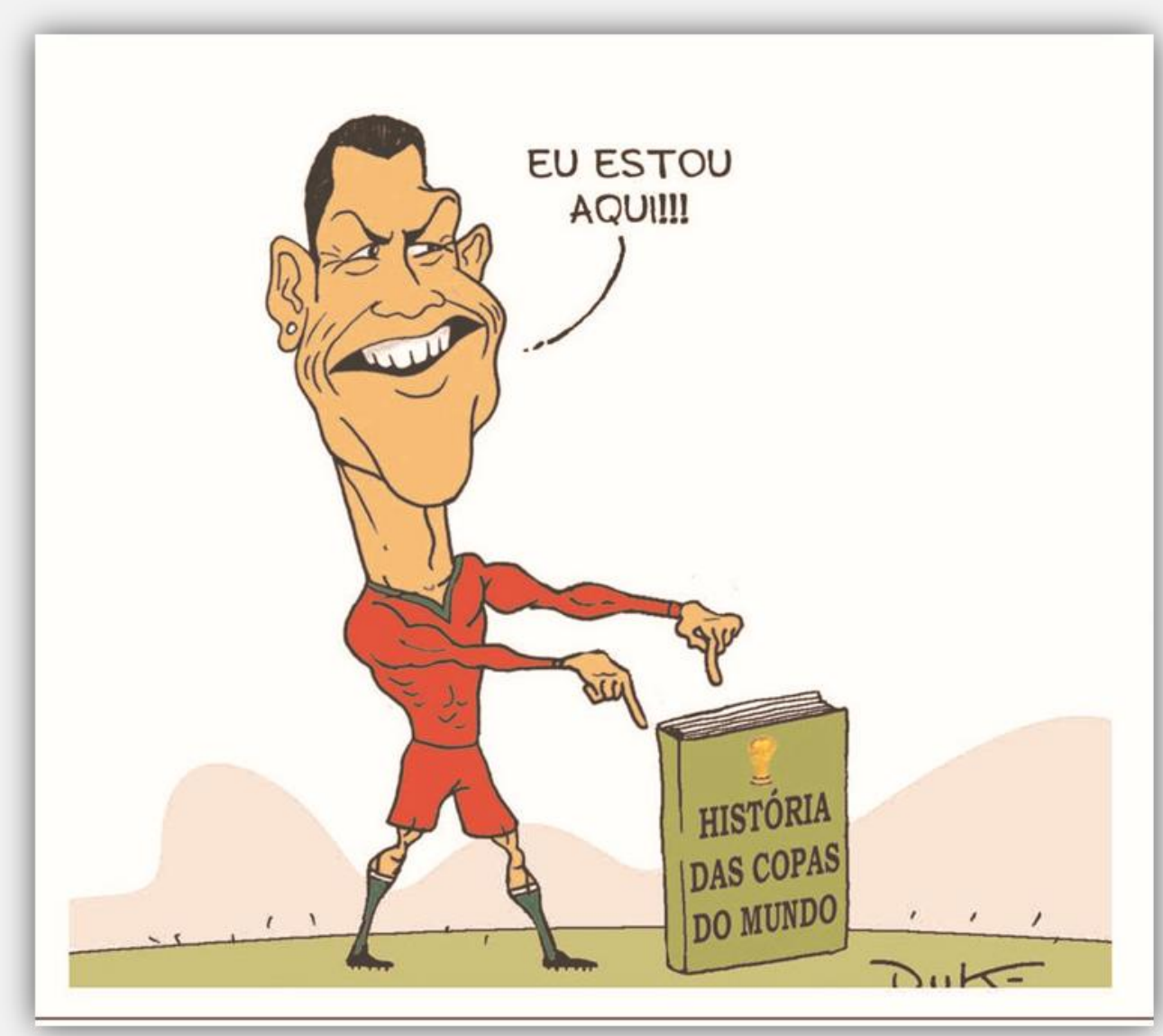

Sábado, 16 de junho de 2018. 


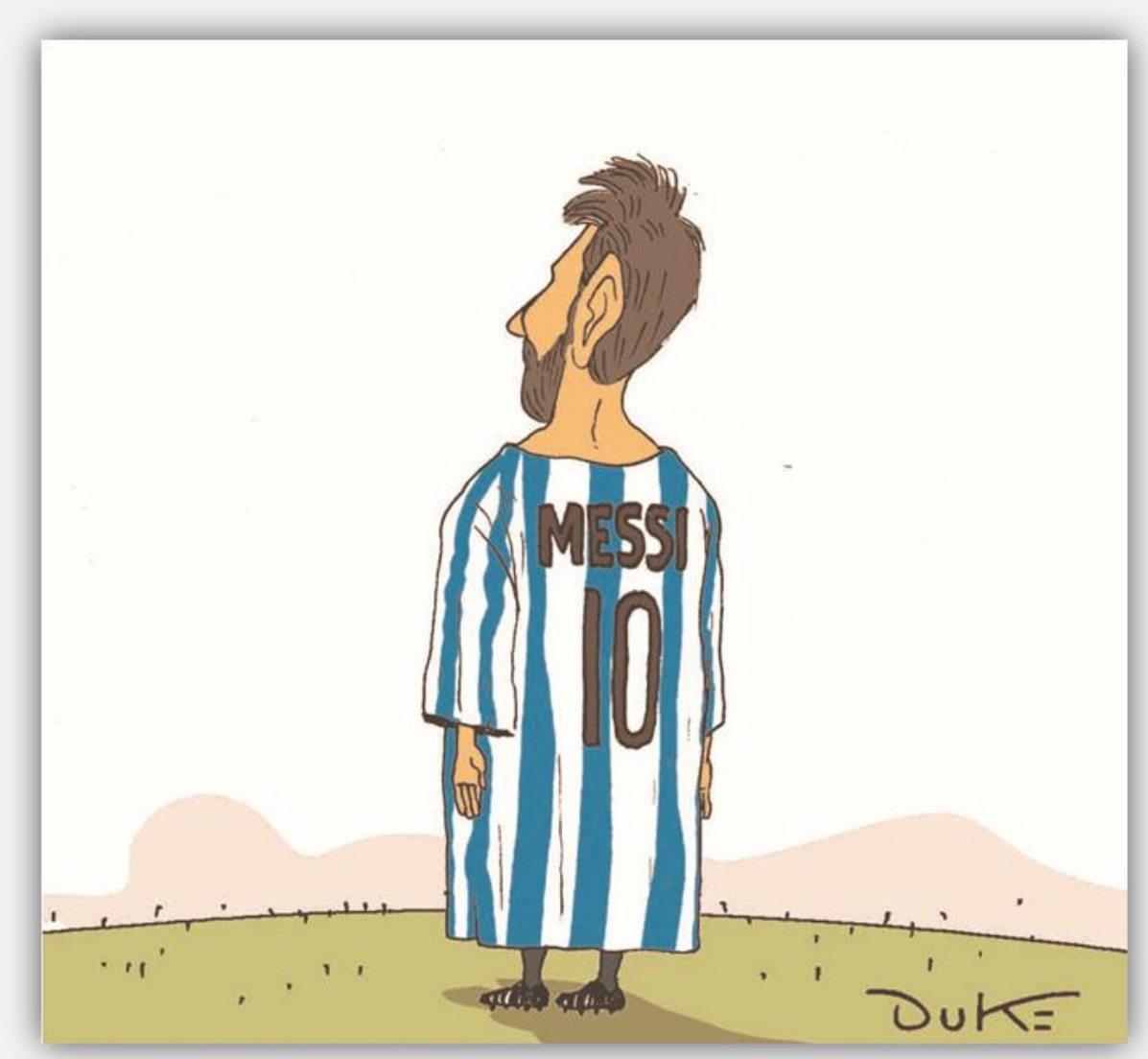

Domingo, 17 de junho de 2018. 


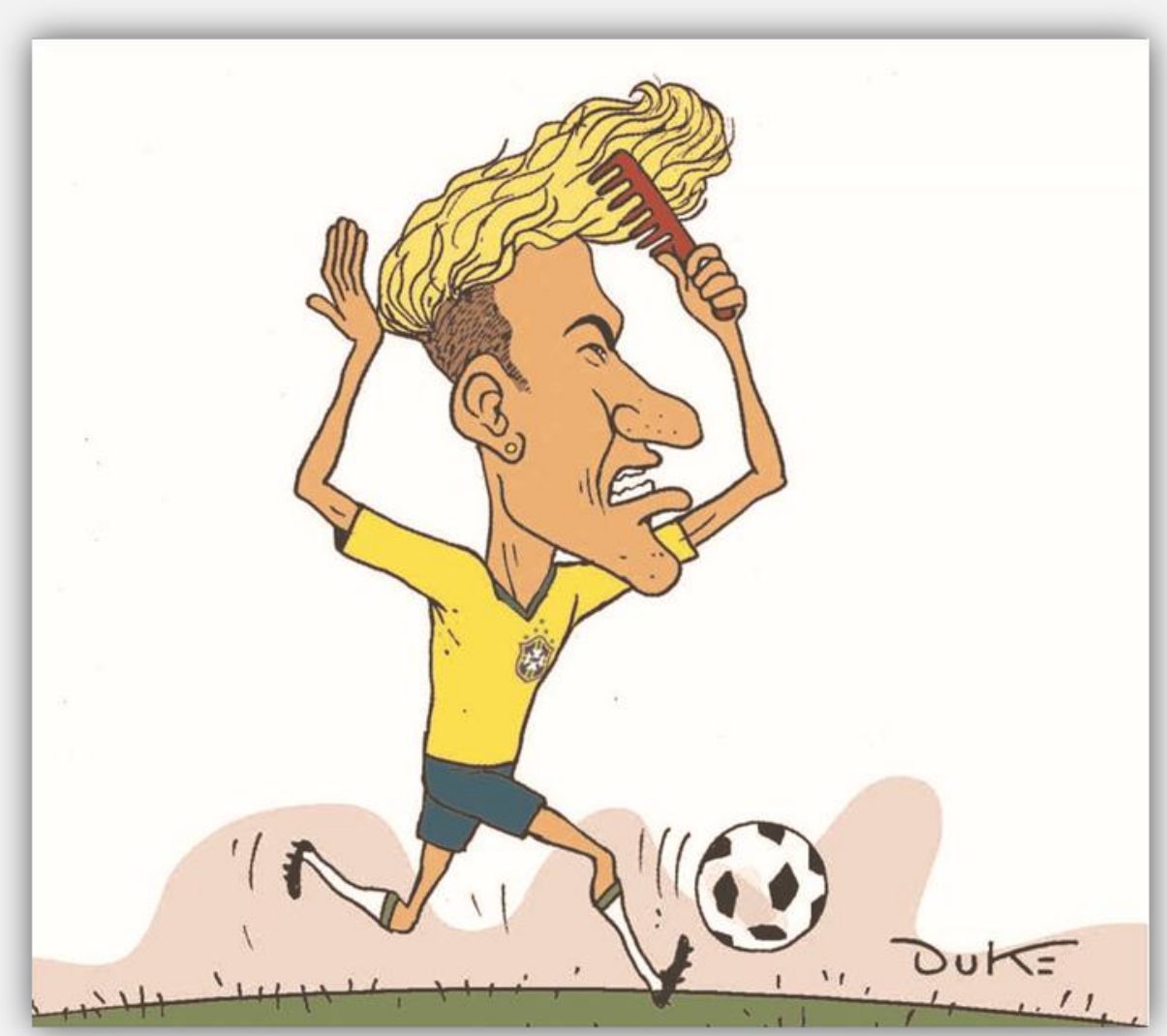

2ª-feira, 18 de junho de 2018. 


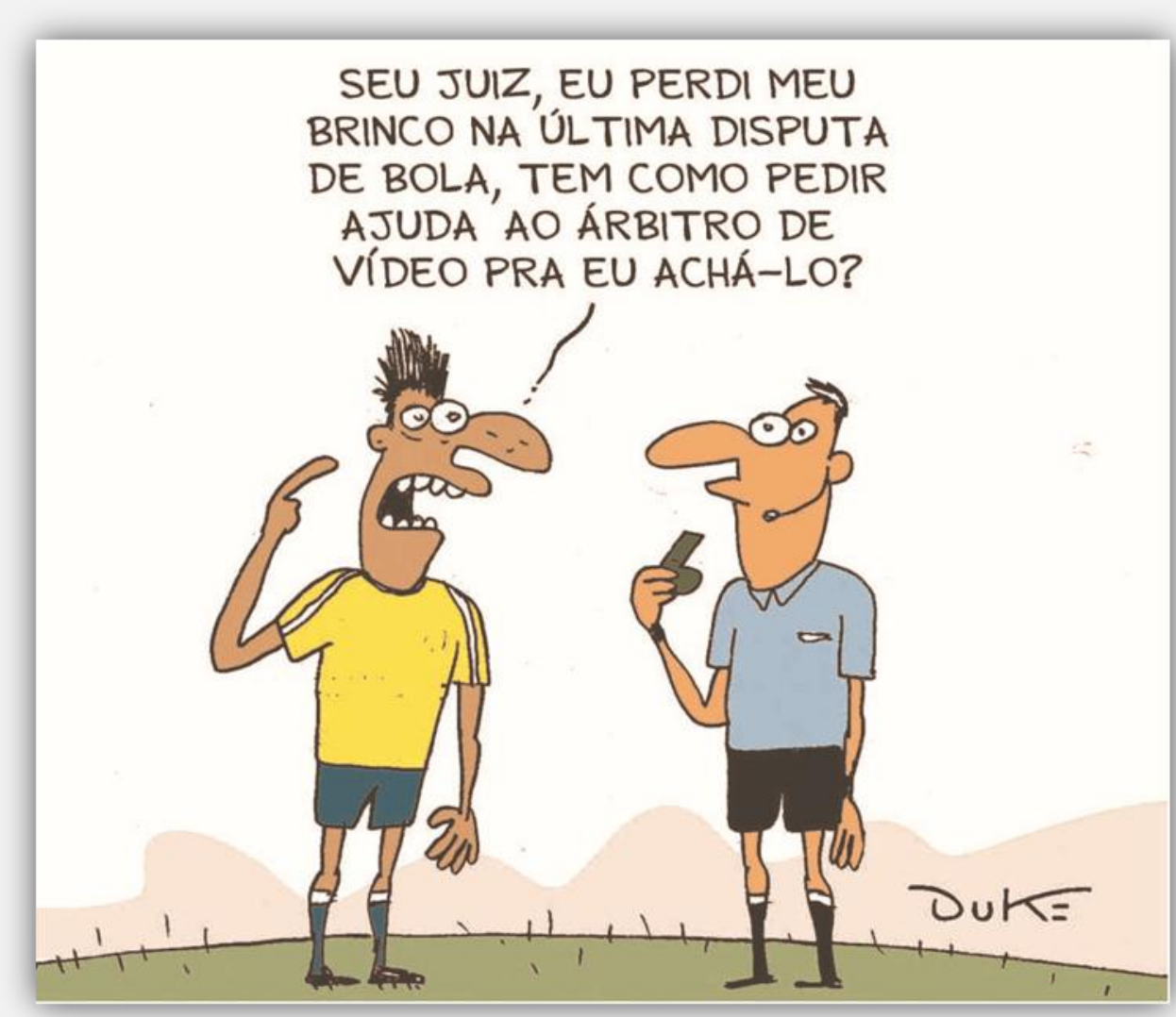




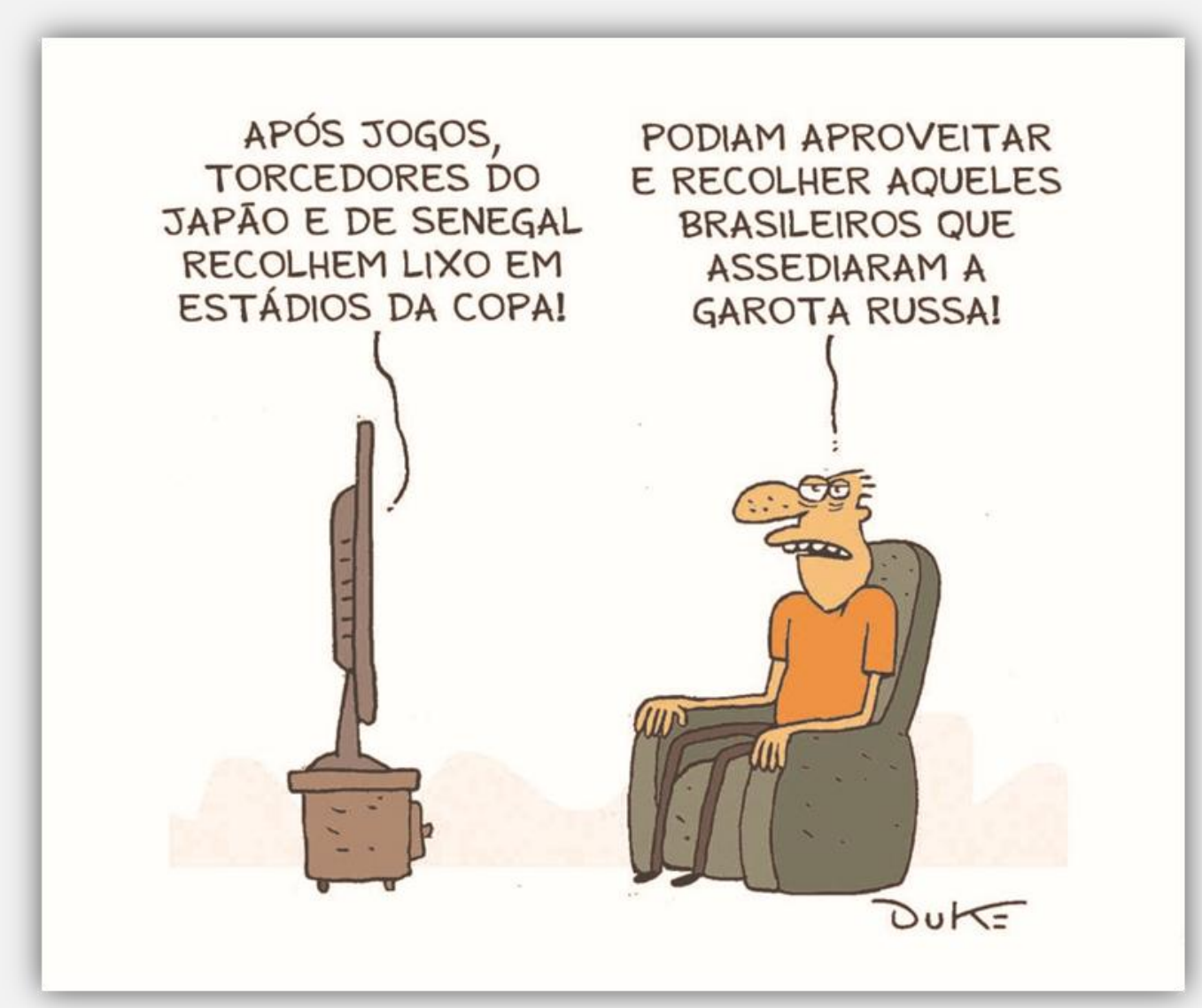




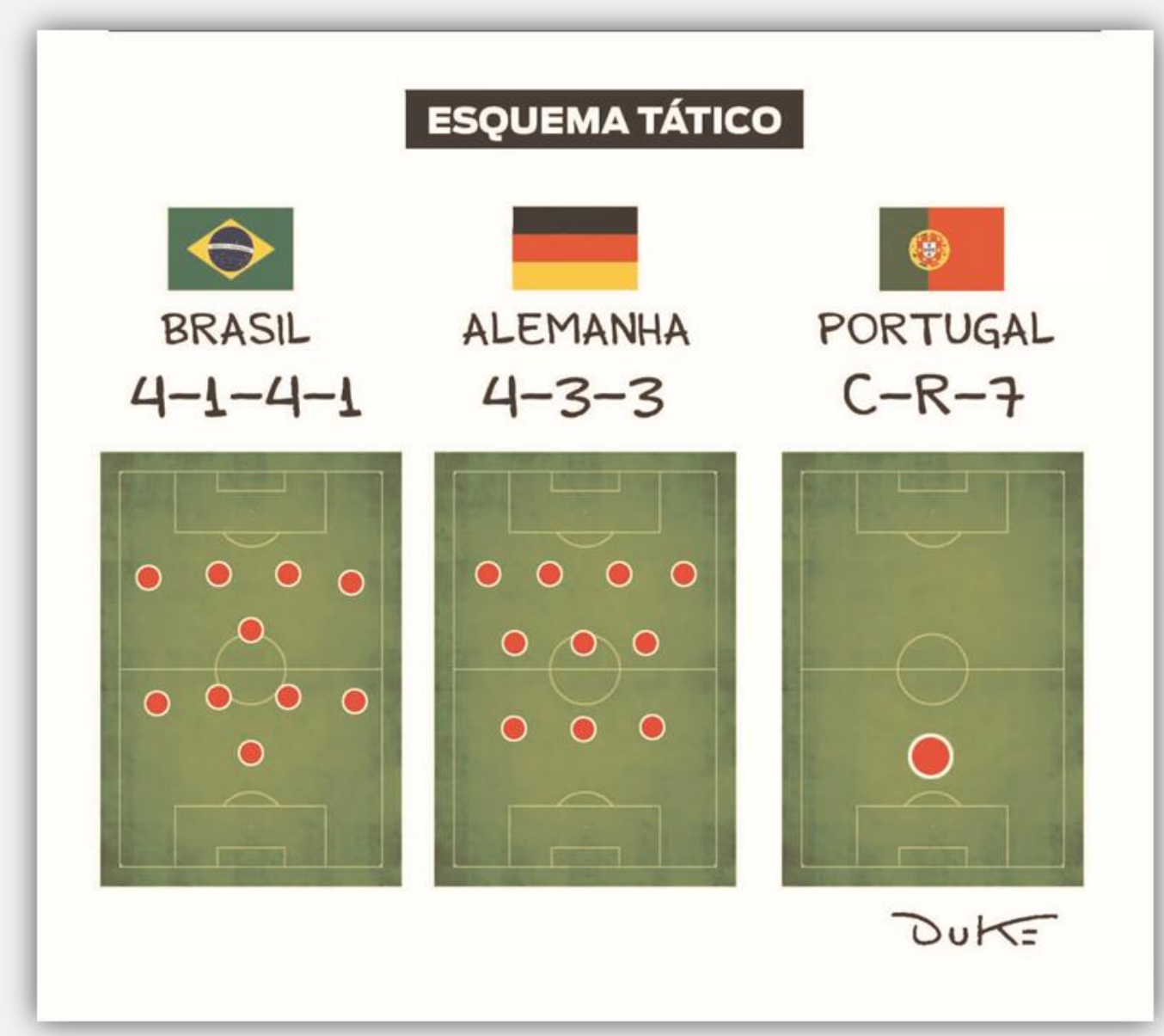




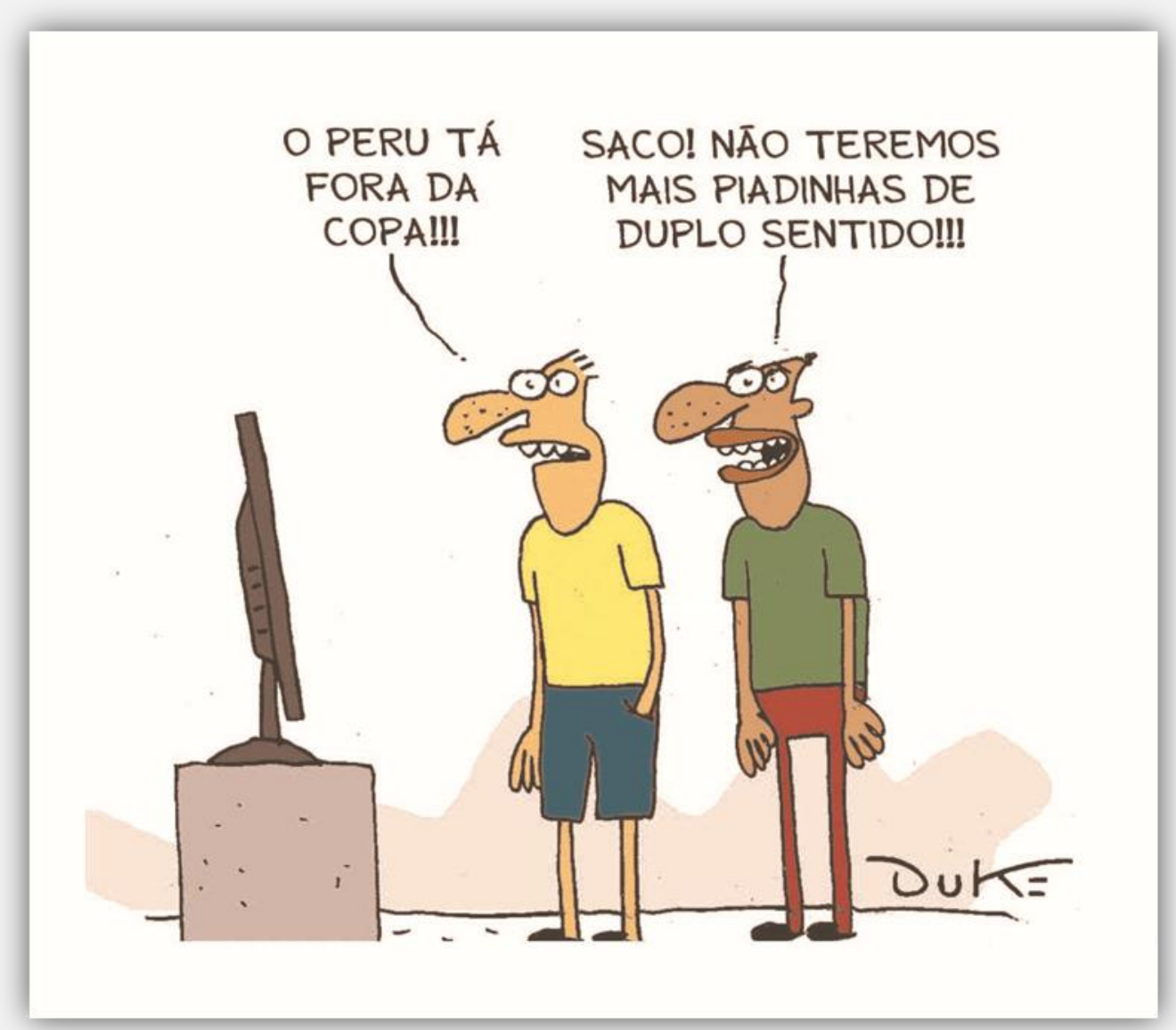

6ª-feira, 22 de junho de 2018. 


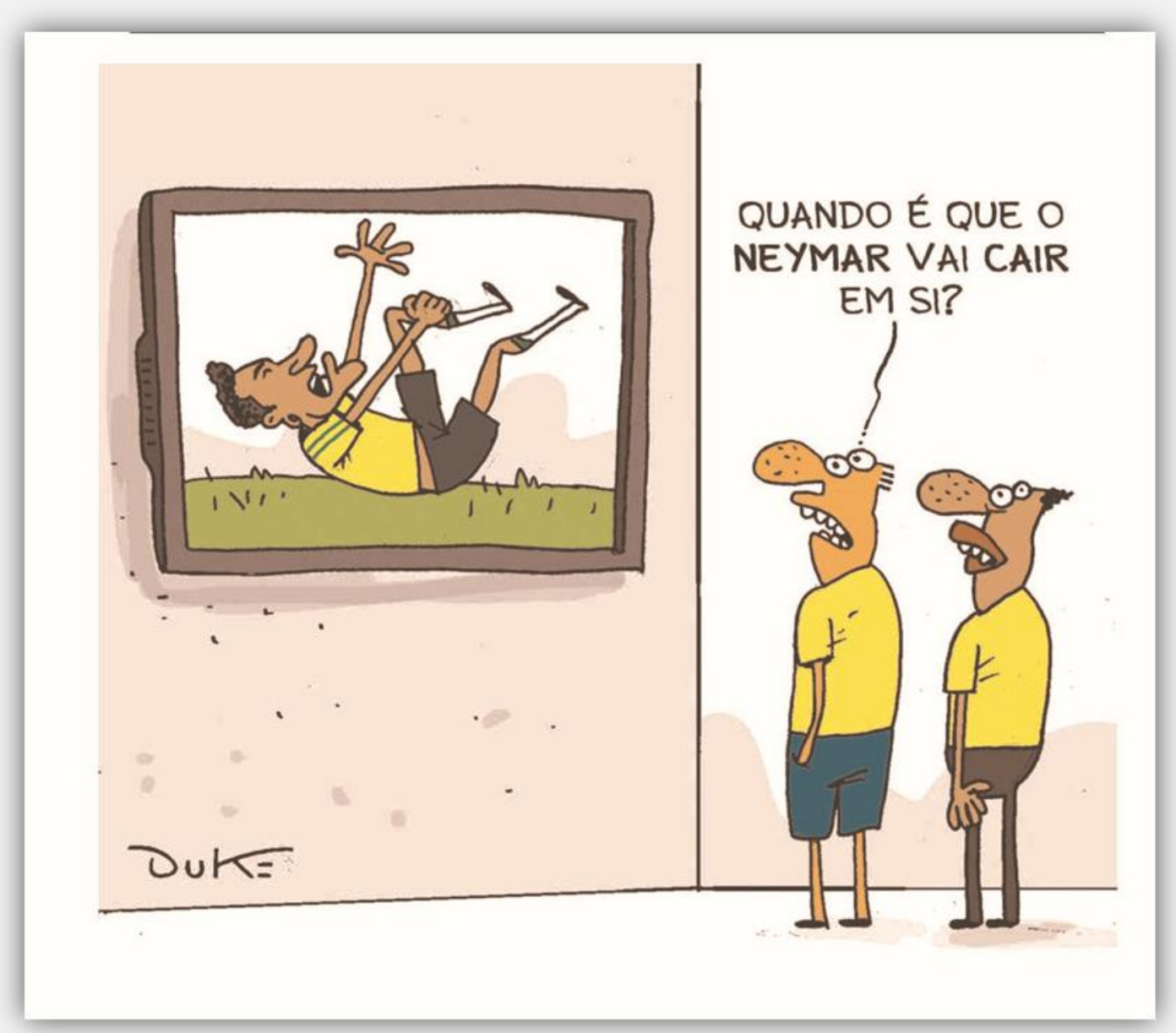




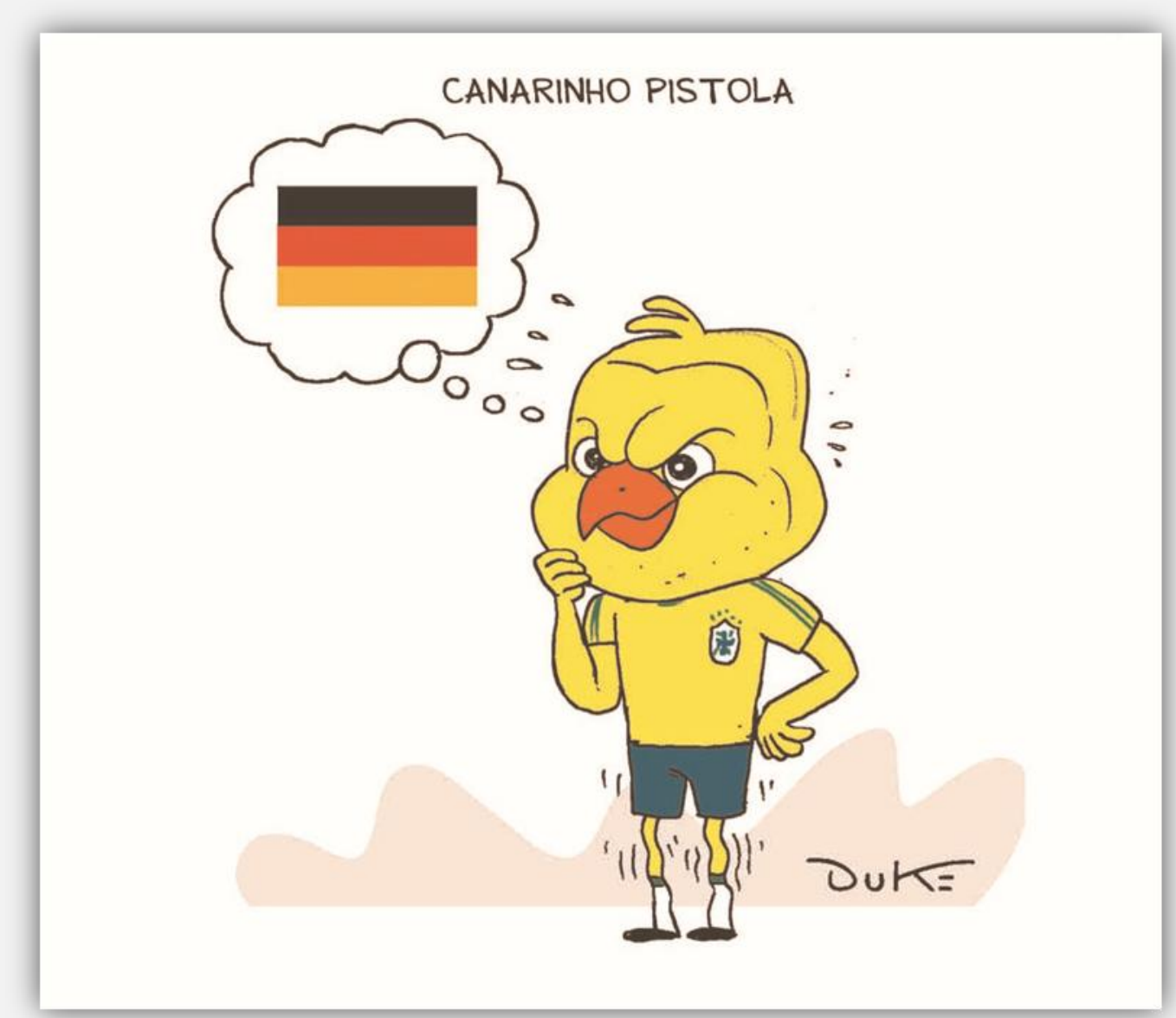




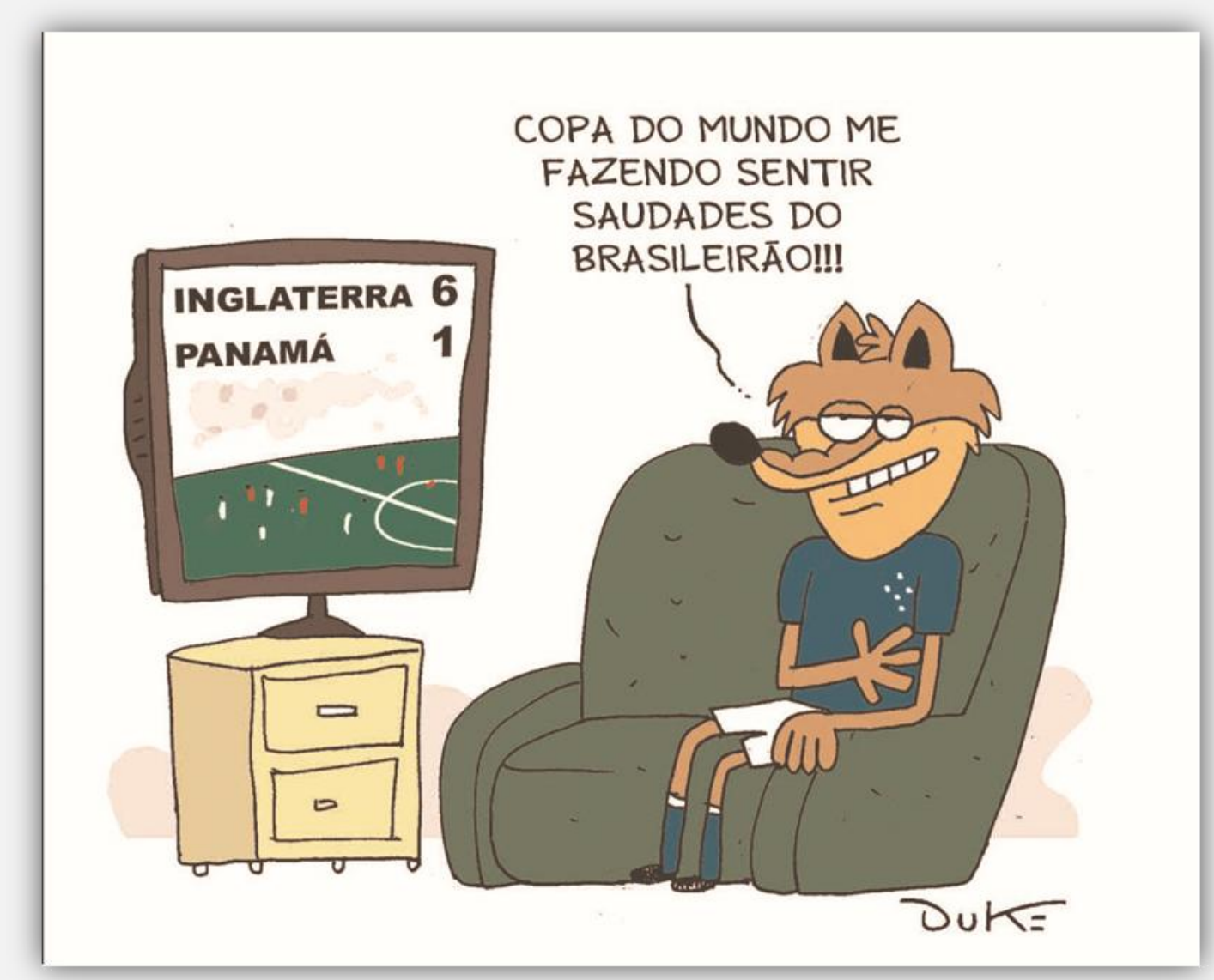

$2^{a}$-feira, 25 de junho de 2018. 




3-a-feira, 26 de junho de 2018. 


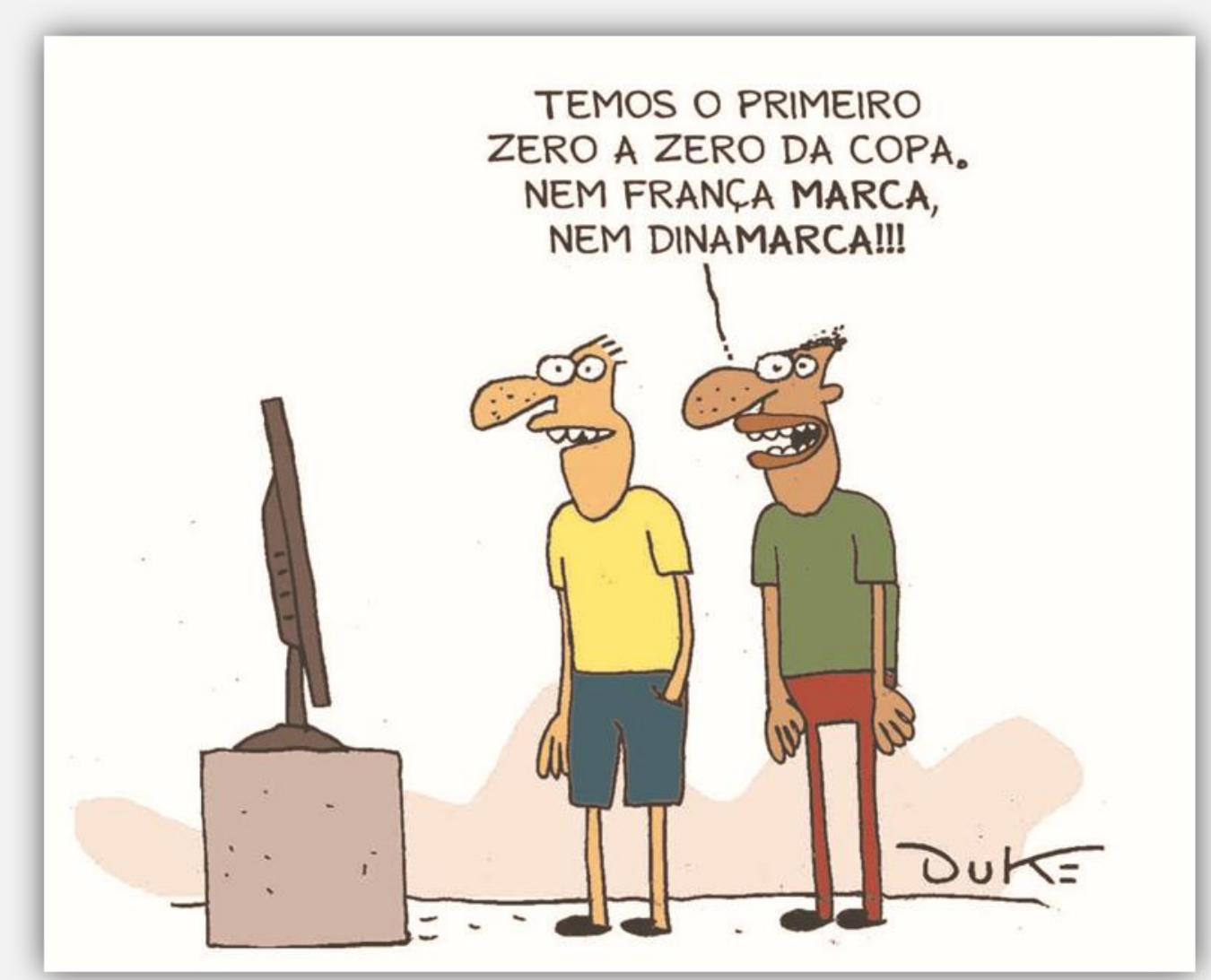

4ª-feira, 27 de junho de 2018. 


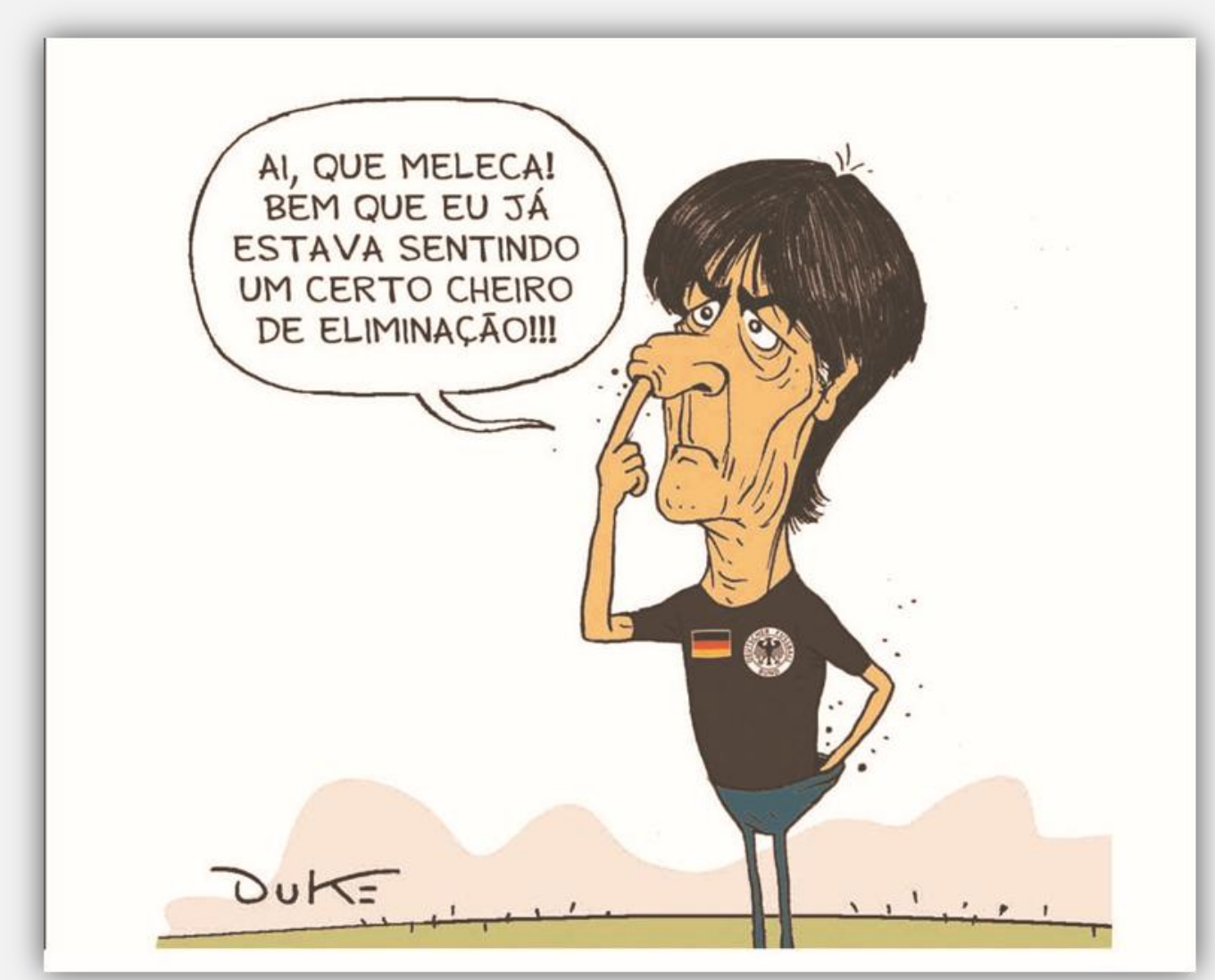


FuLiA / UFMG - Charges da Copa na Rússia

"ESTE NÚMERO NOVE ENCONTRA-SE FORA DE ÁREA OU DESLIGADO"

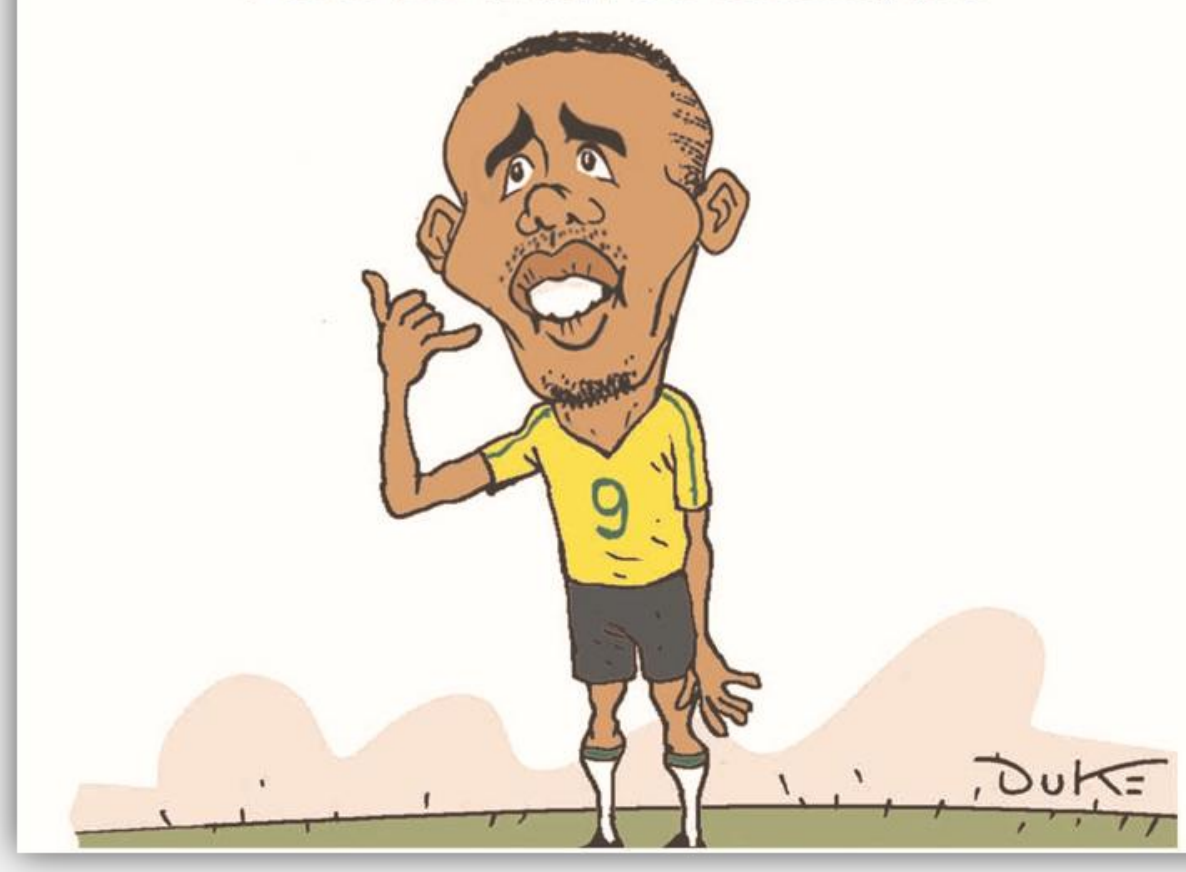

6⿳⺈-feira, 29 de junho de 2018.

242 
AFINAL, O VAR É BOM

OU RUIM PRO FUTEBOL?

O JOSÉ ROBERTO WRIGHT DISSE QUE É RUIM!

AH, ENTÃO É ÓTIMO!!!

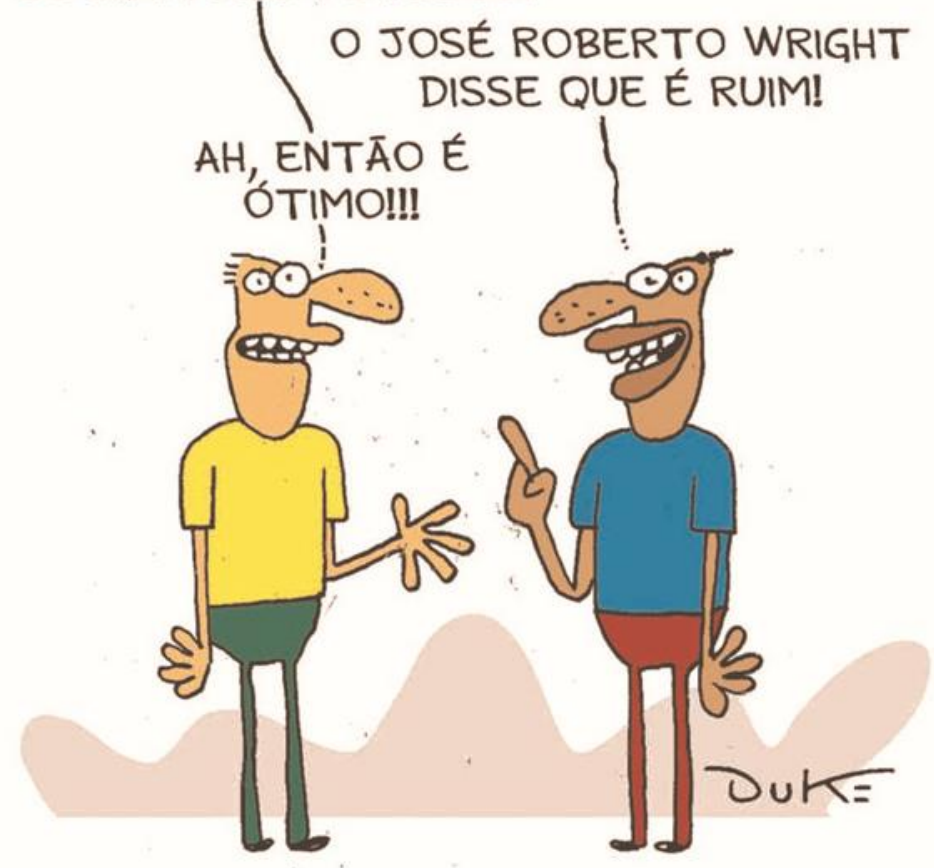




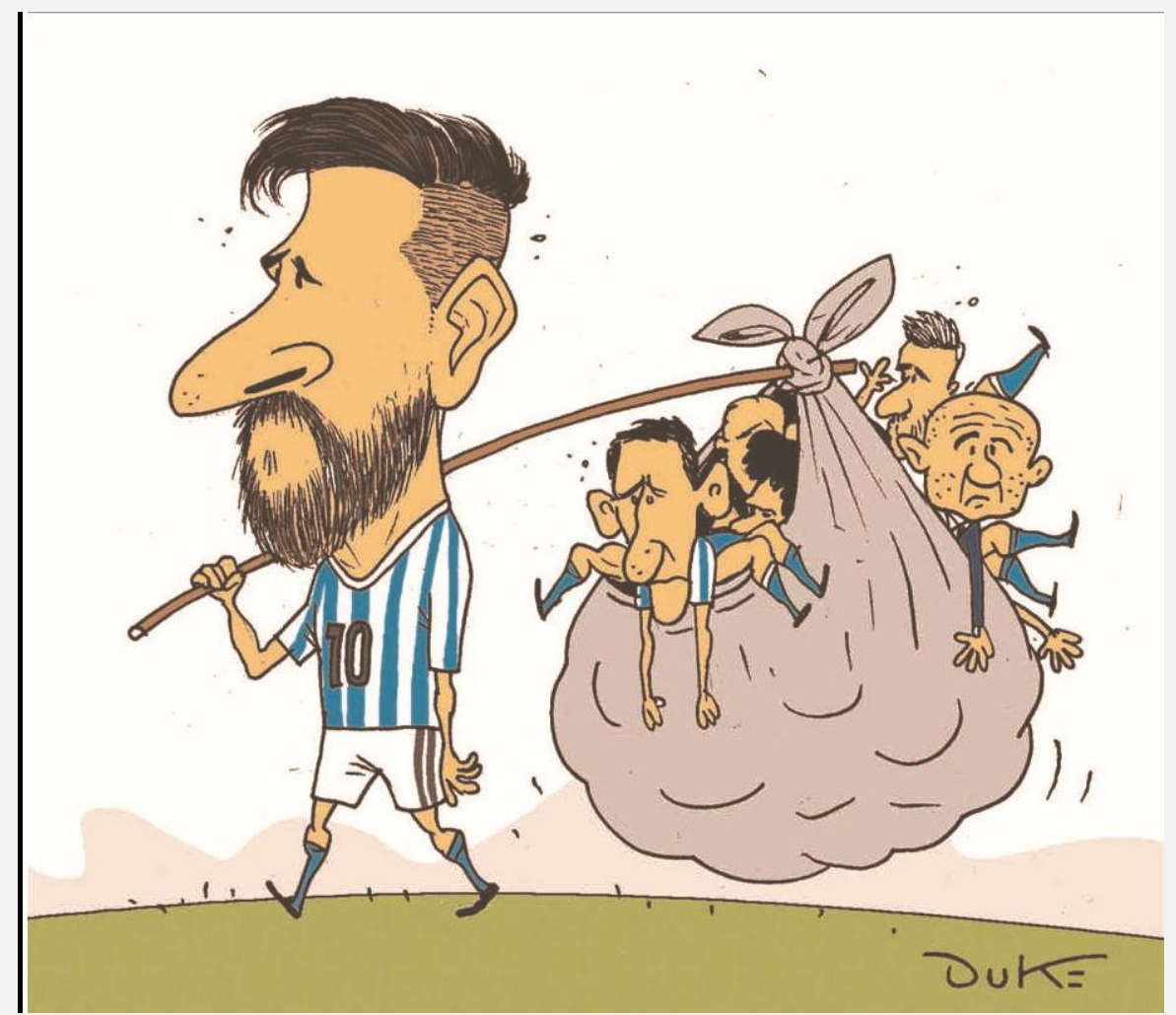




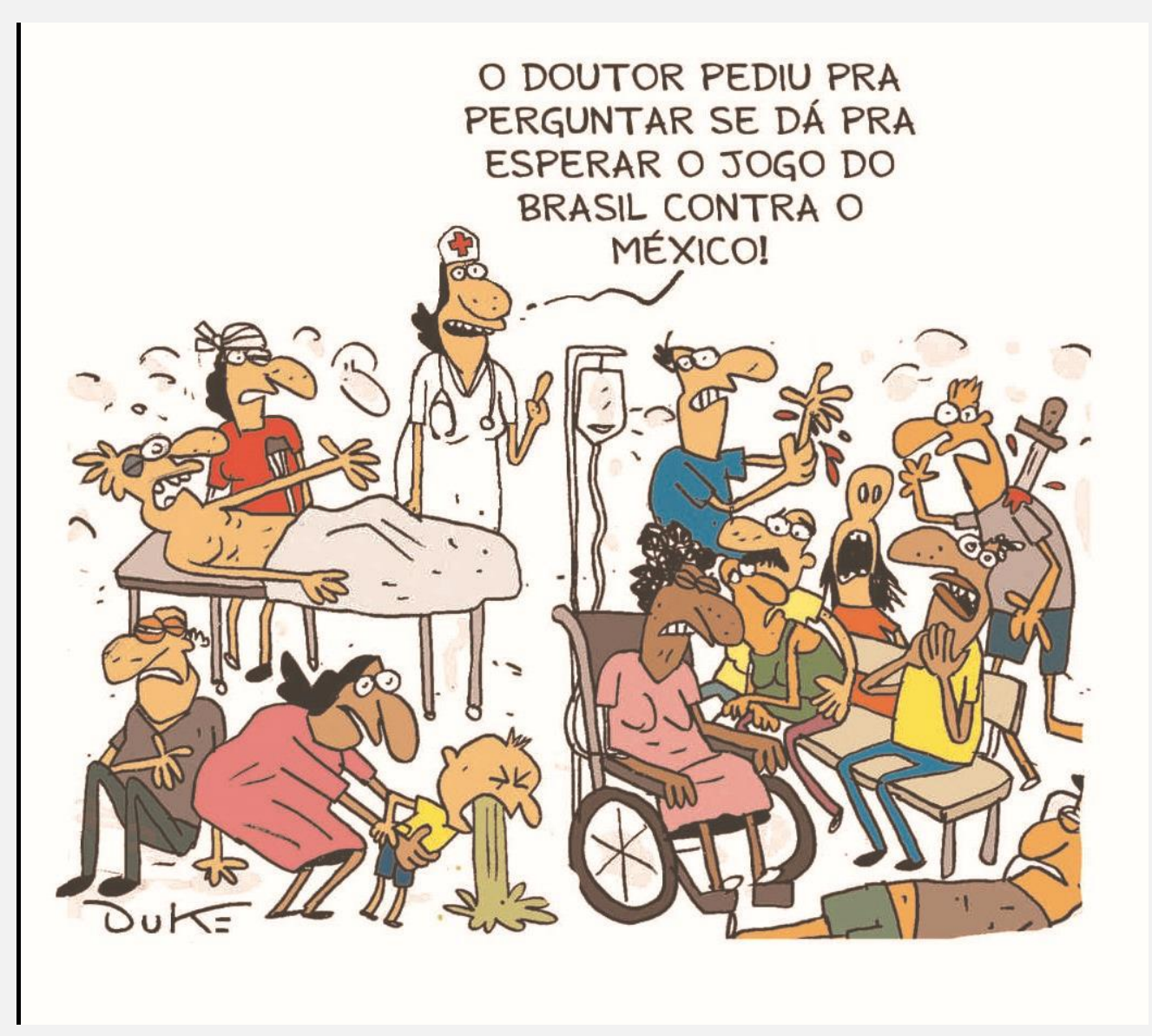




\section{PI PI PI PIIOo. . „PISTTOLA}

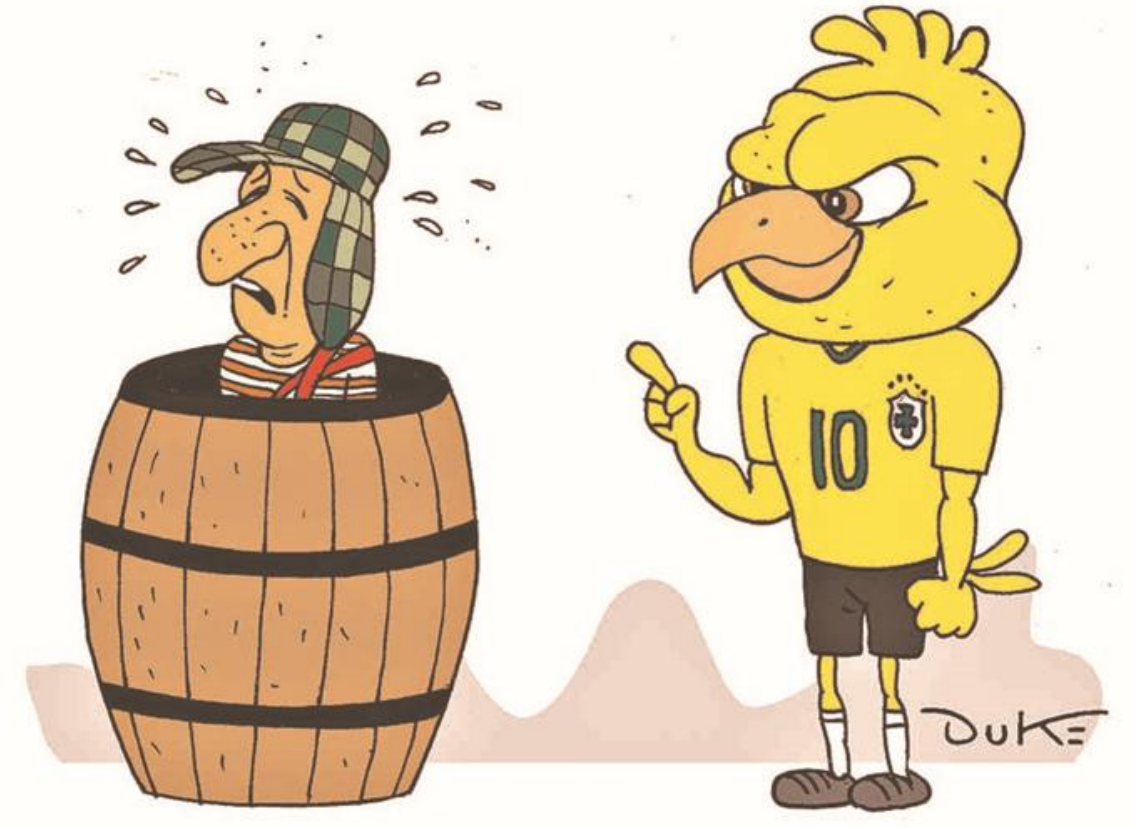




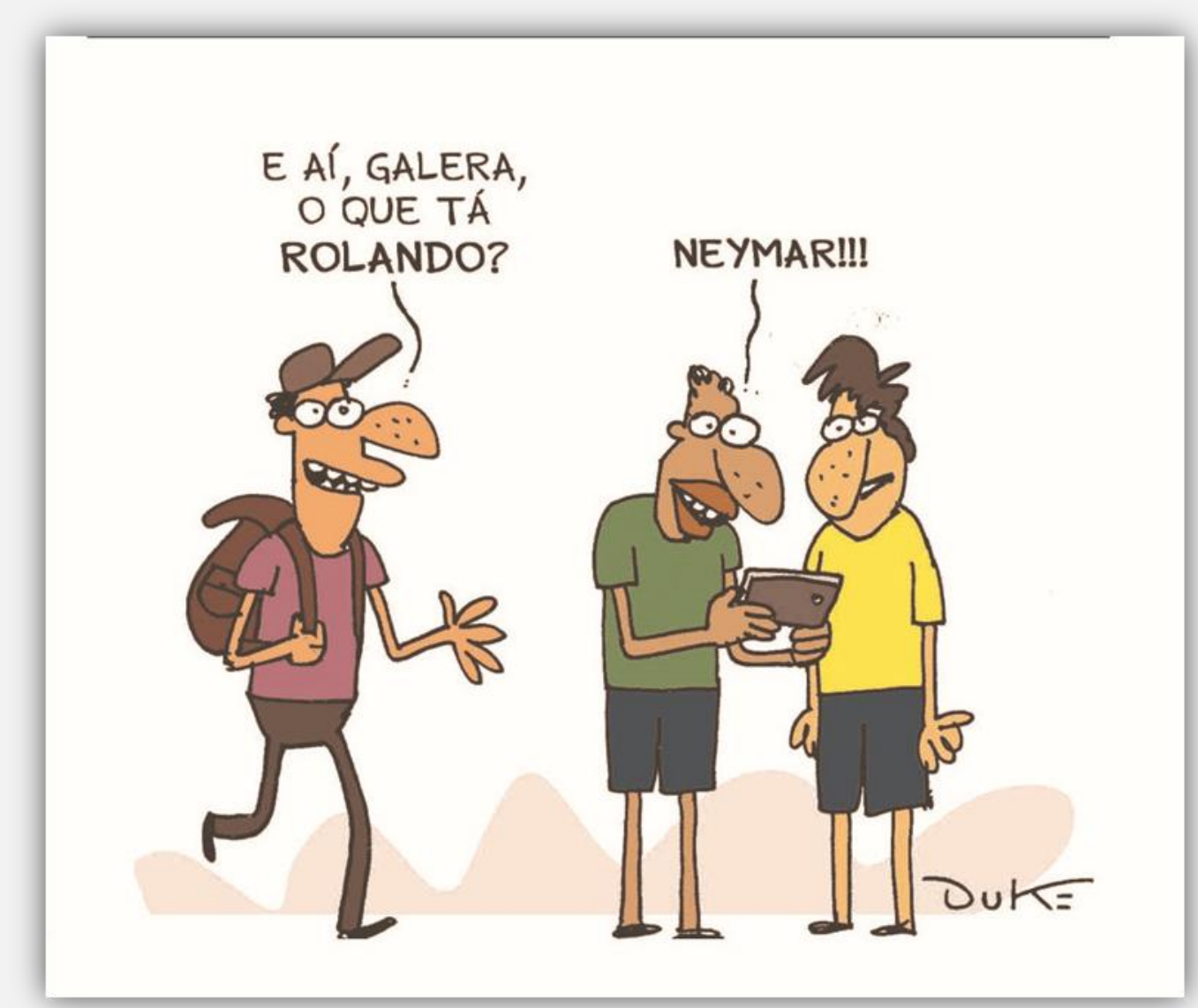






5-feira, 05 de julho de 2018. 


\section{CANARINHO PISTOLA X CANARINHO-BELGA}

AINDA BEM QUE NOSSO DUELOÉ EM CAMPO, NĀO DE CANTO!






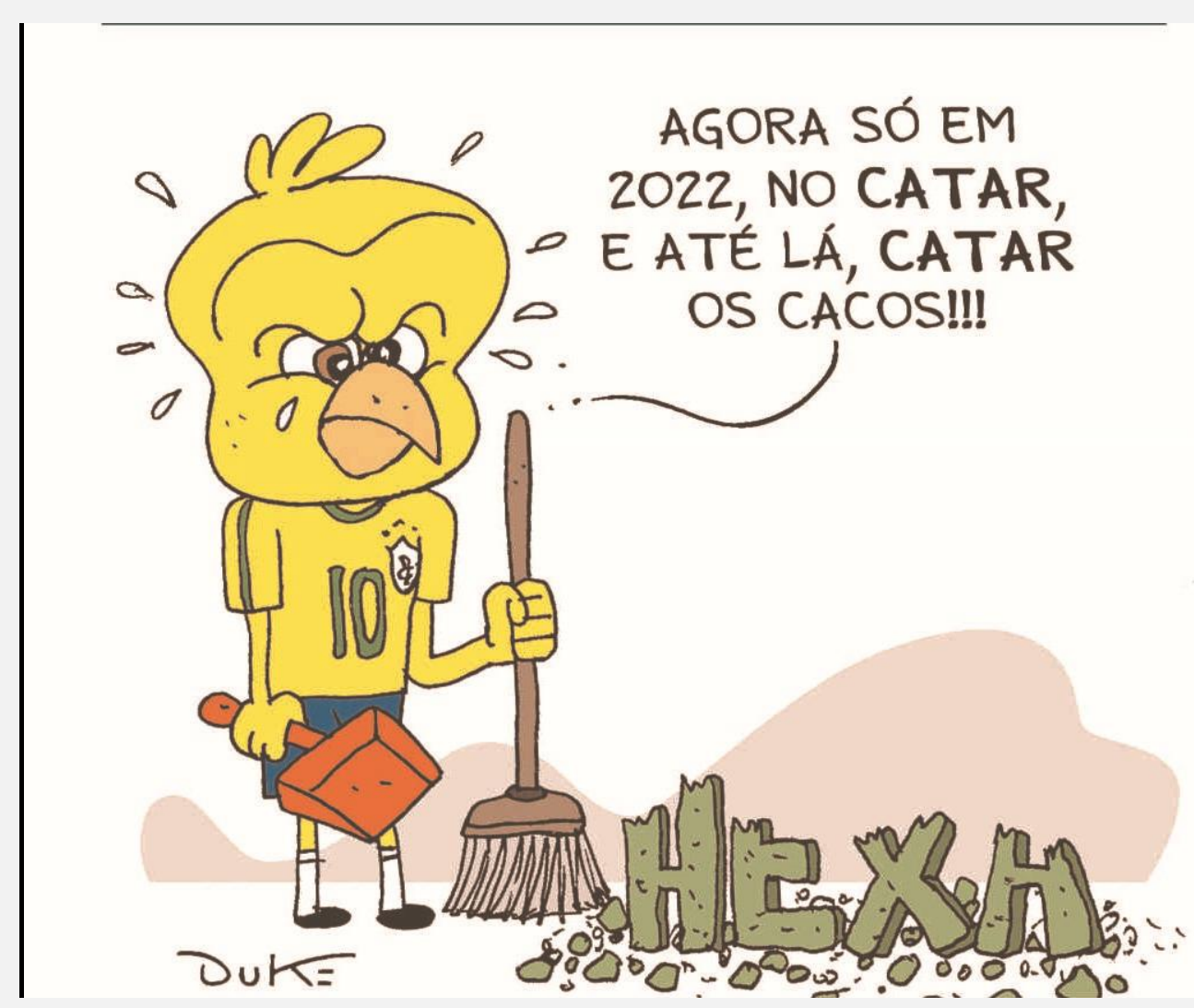




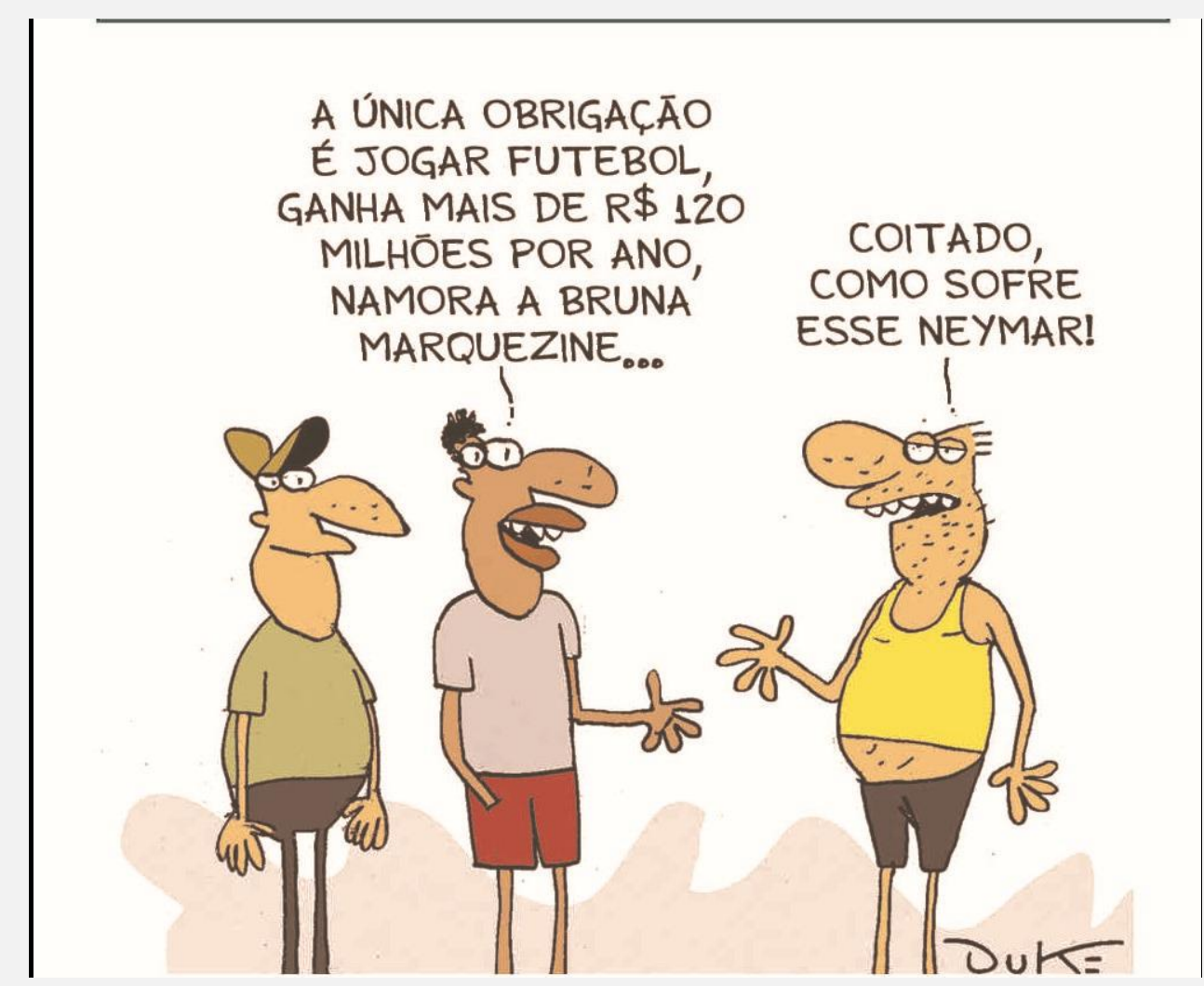









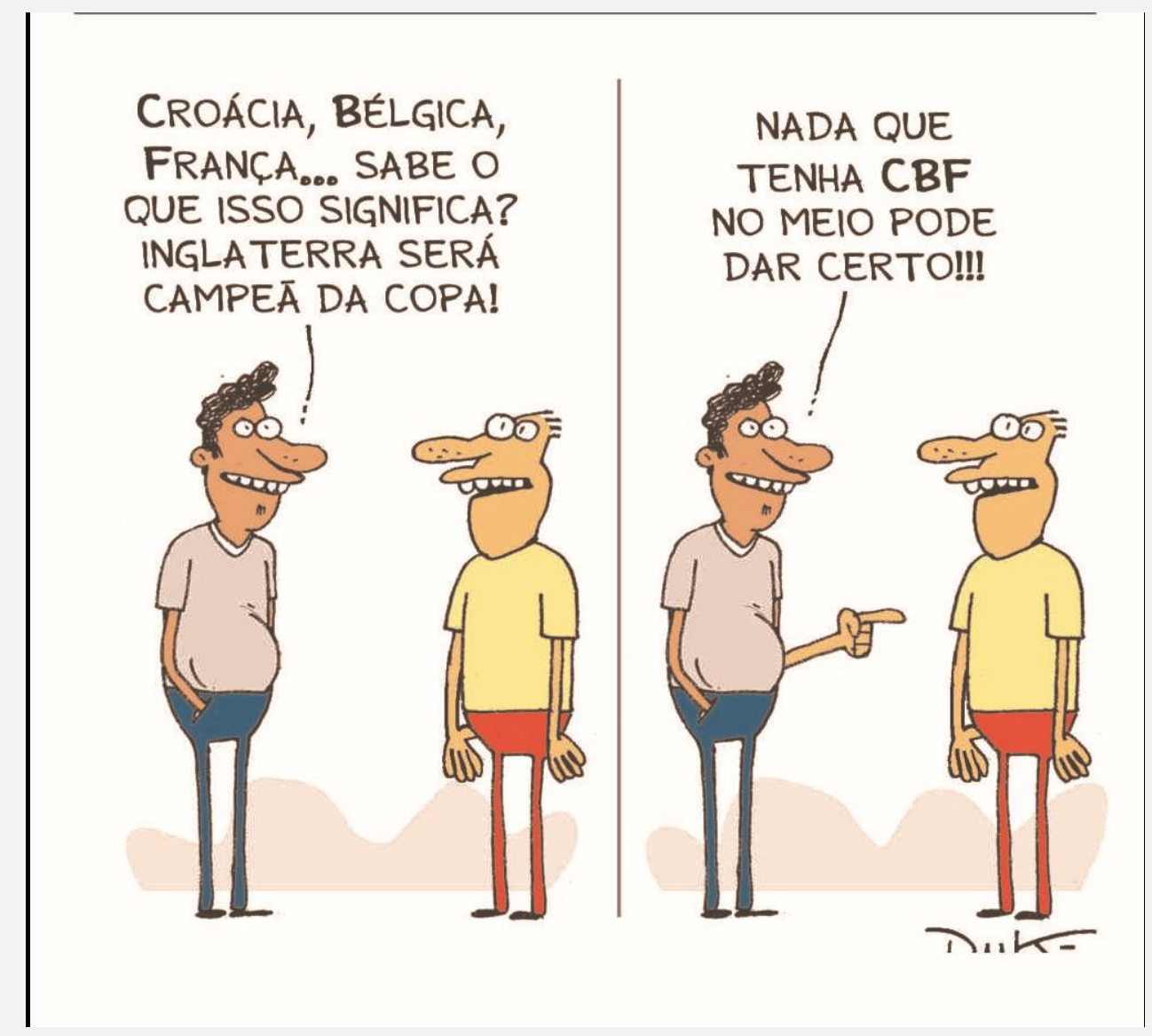




O BRASIL FOI
ELIMINADO PELA
BELLGICA QUE FOI
NOS LIVRAMOS
OUTRO 7 A 1!

ELIMINADA PELA

FRANCA
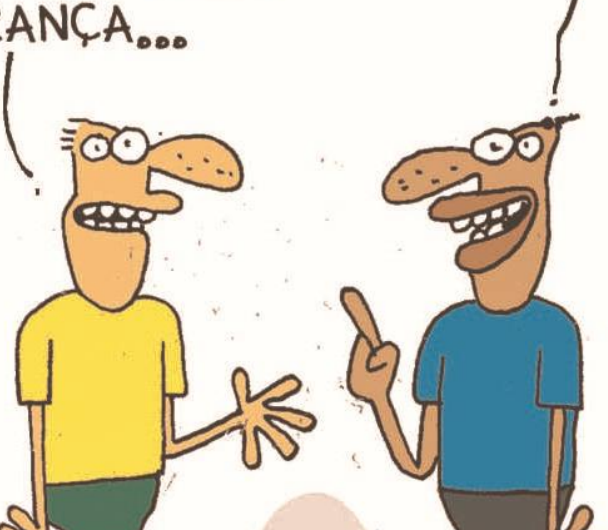

ह

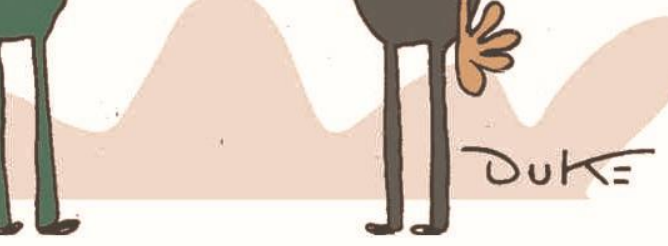




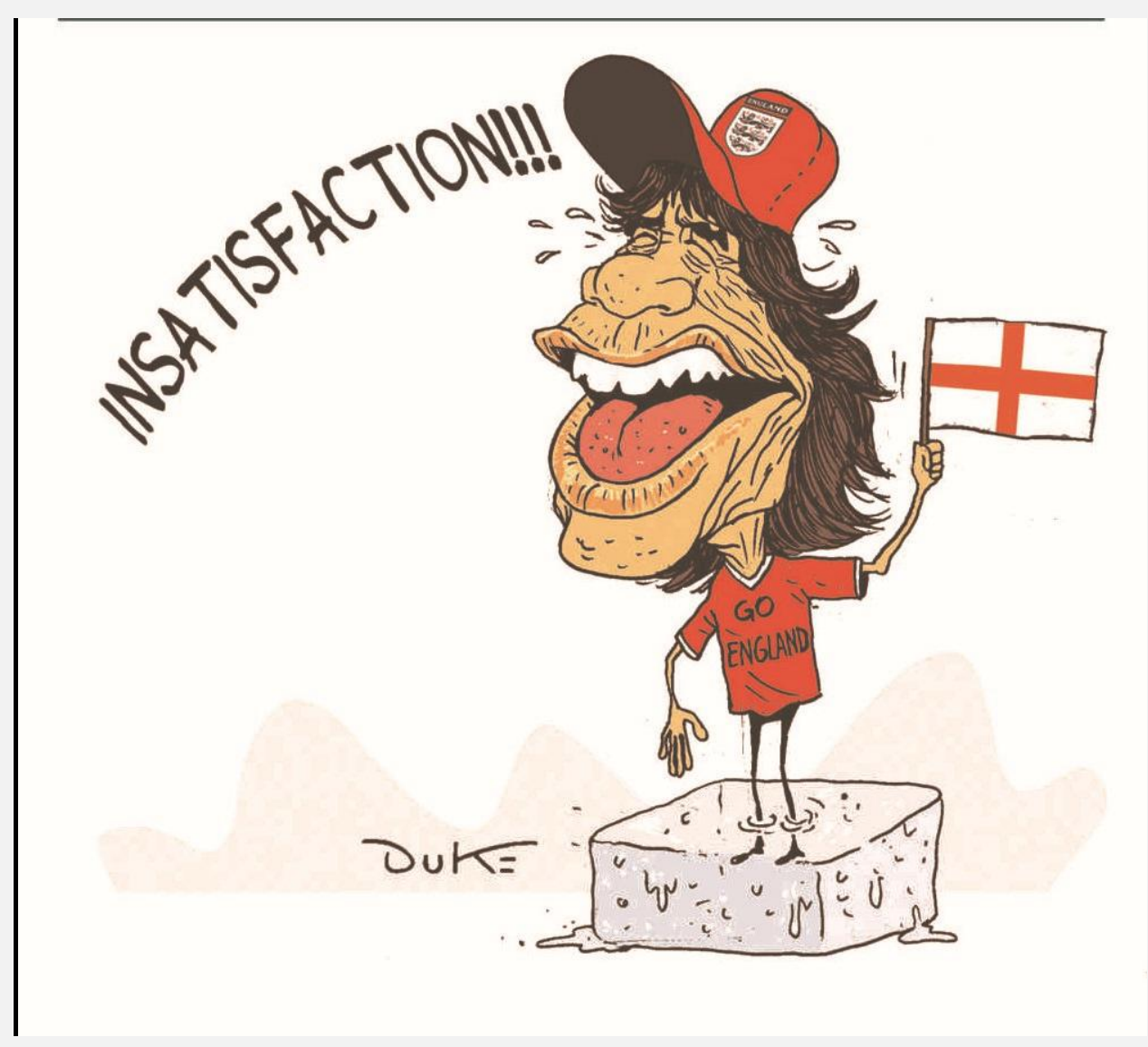




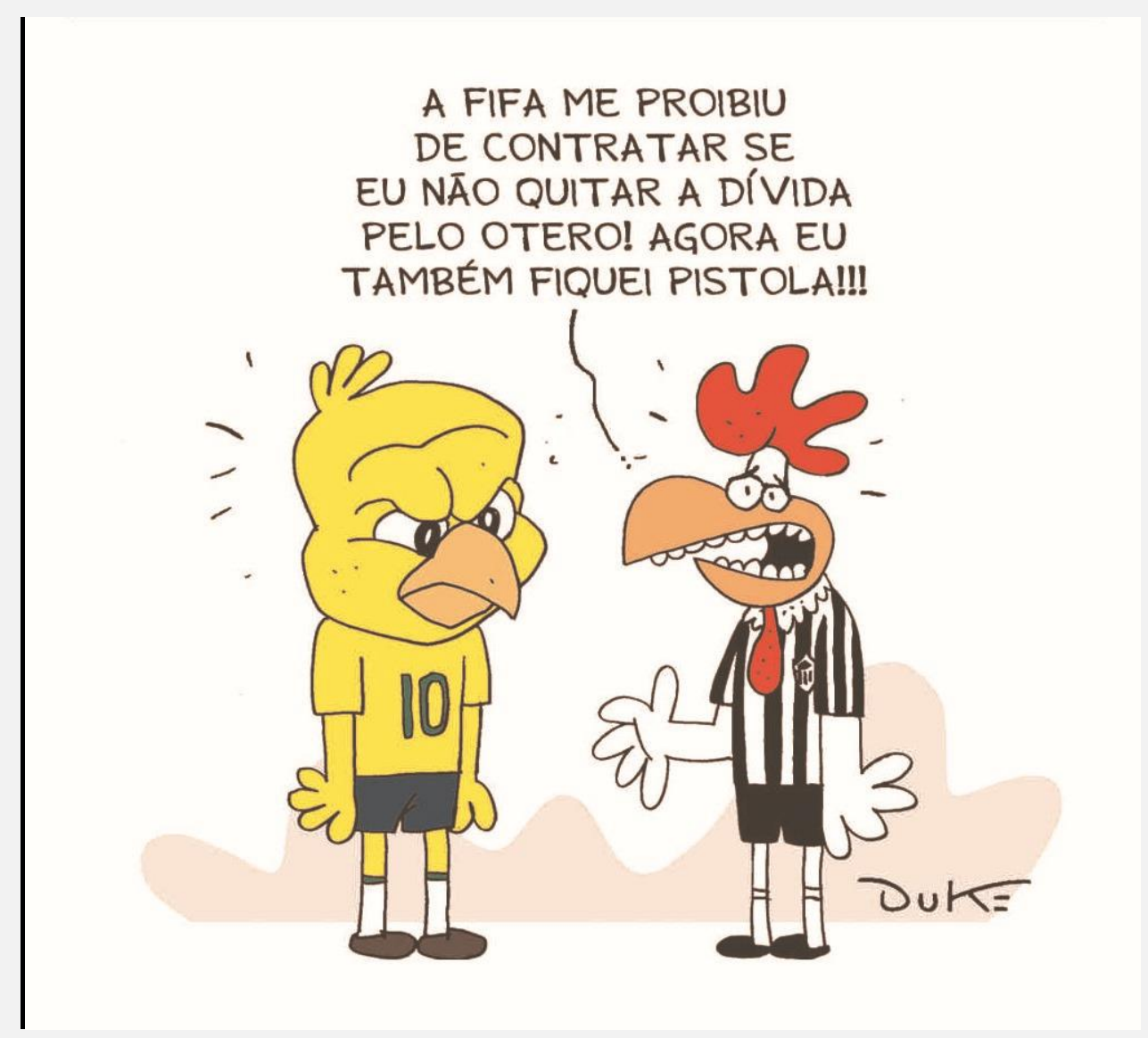


UMA COISA É CERTA:

NEYMAR TEM FEITO

MUITA GENTE ROLAR DE RIR!!!

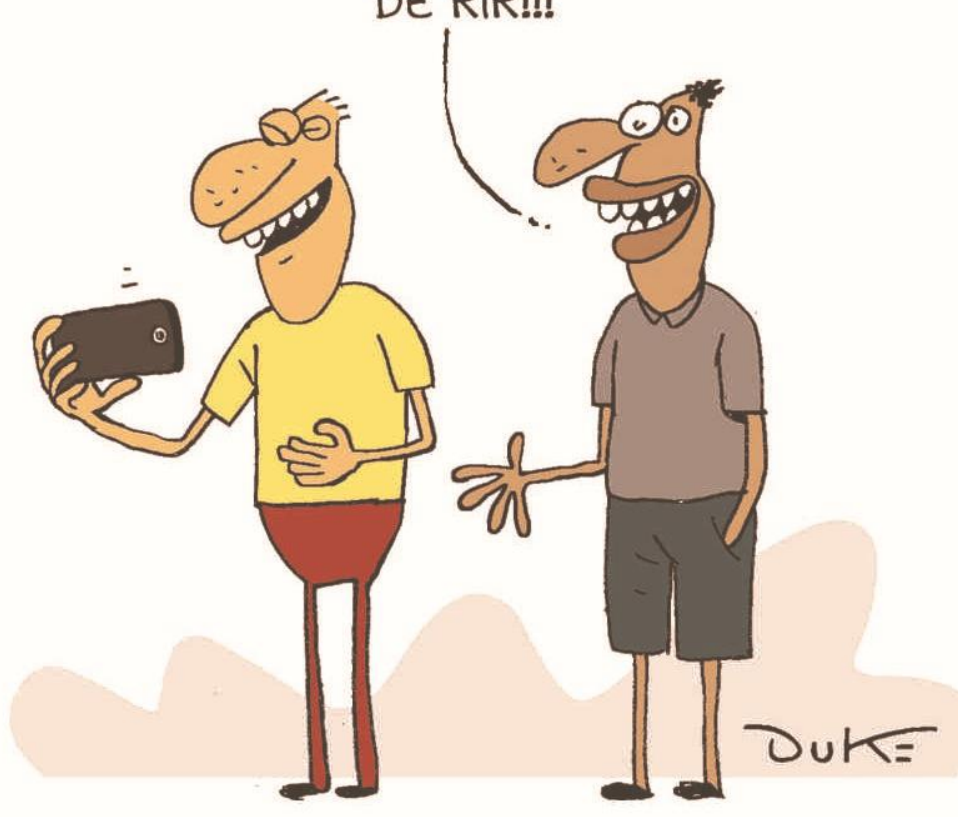


EU TÔ TENTANDO

PARAR DE FAZER PIADA

SOBRE O NEYMAR, MAS

SEMPRE TENHO UMA RECAIDA!!!

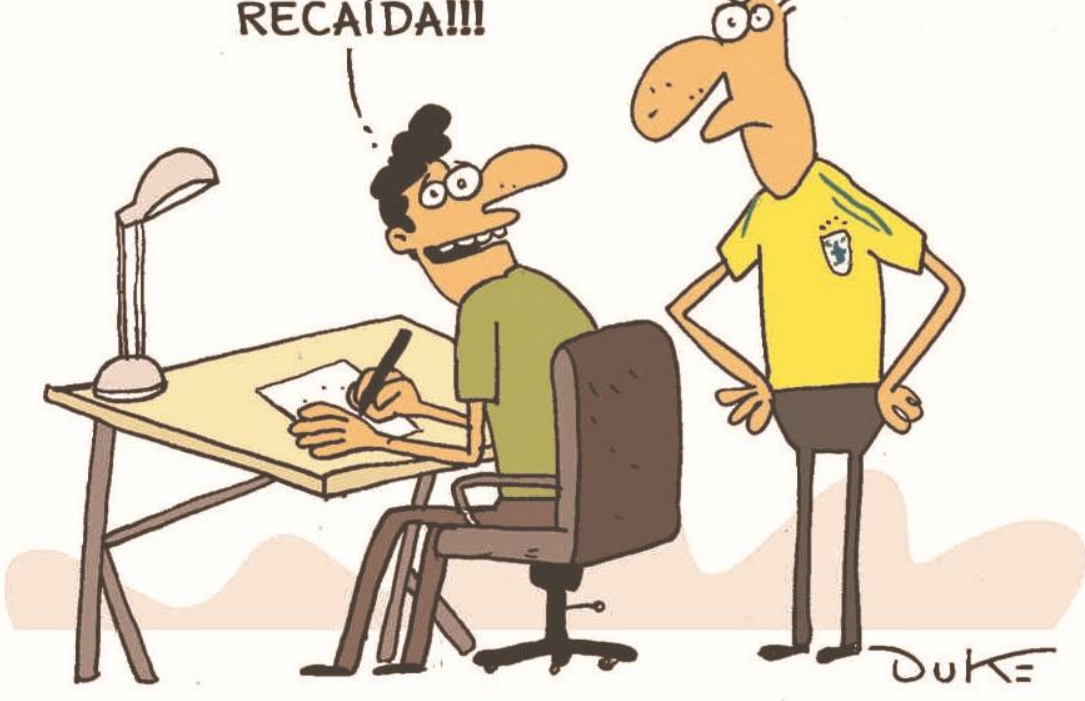




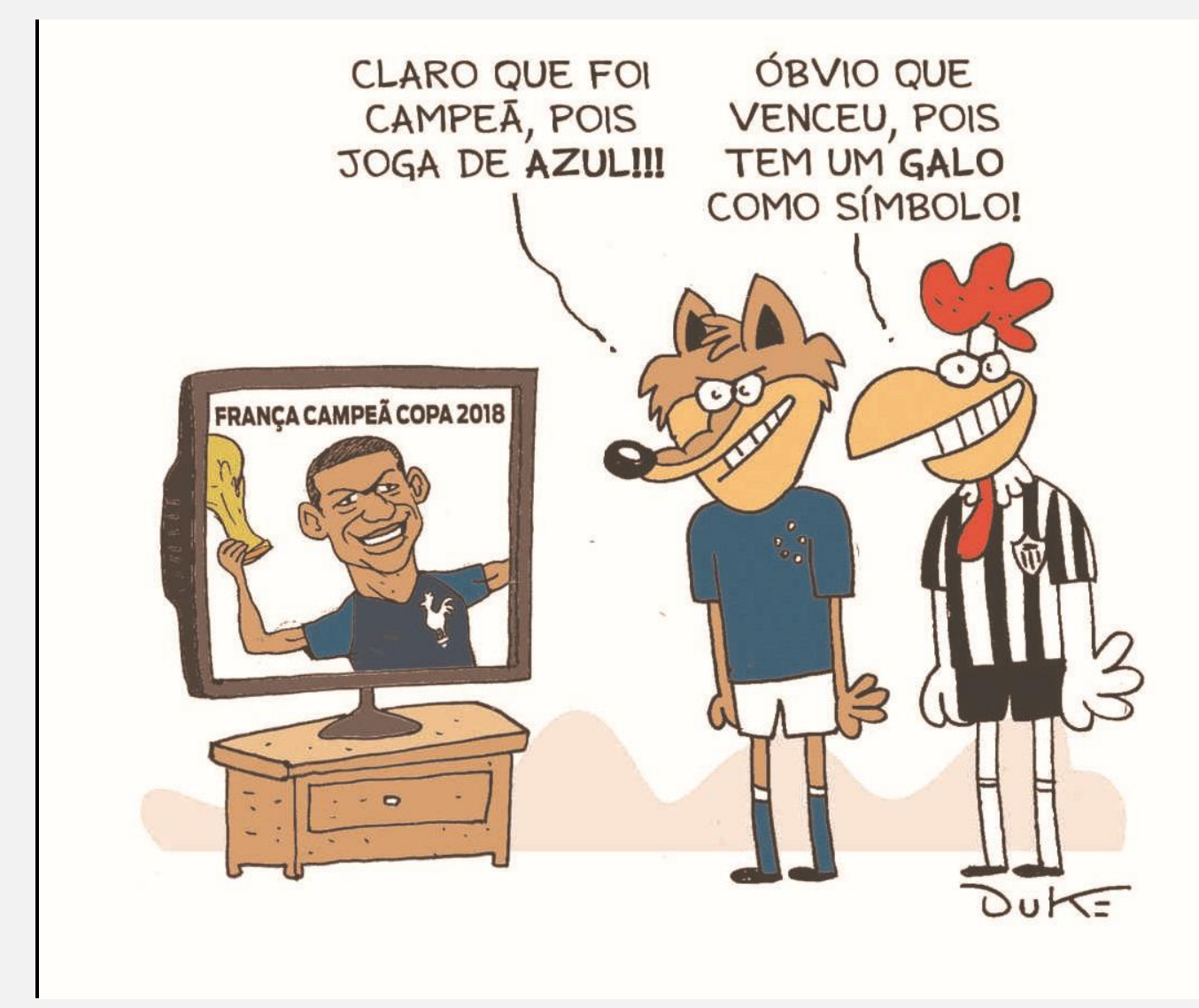




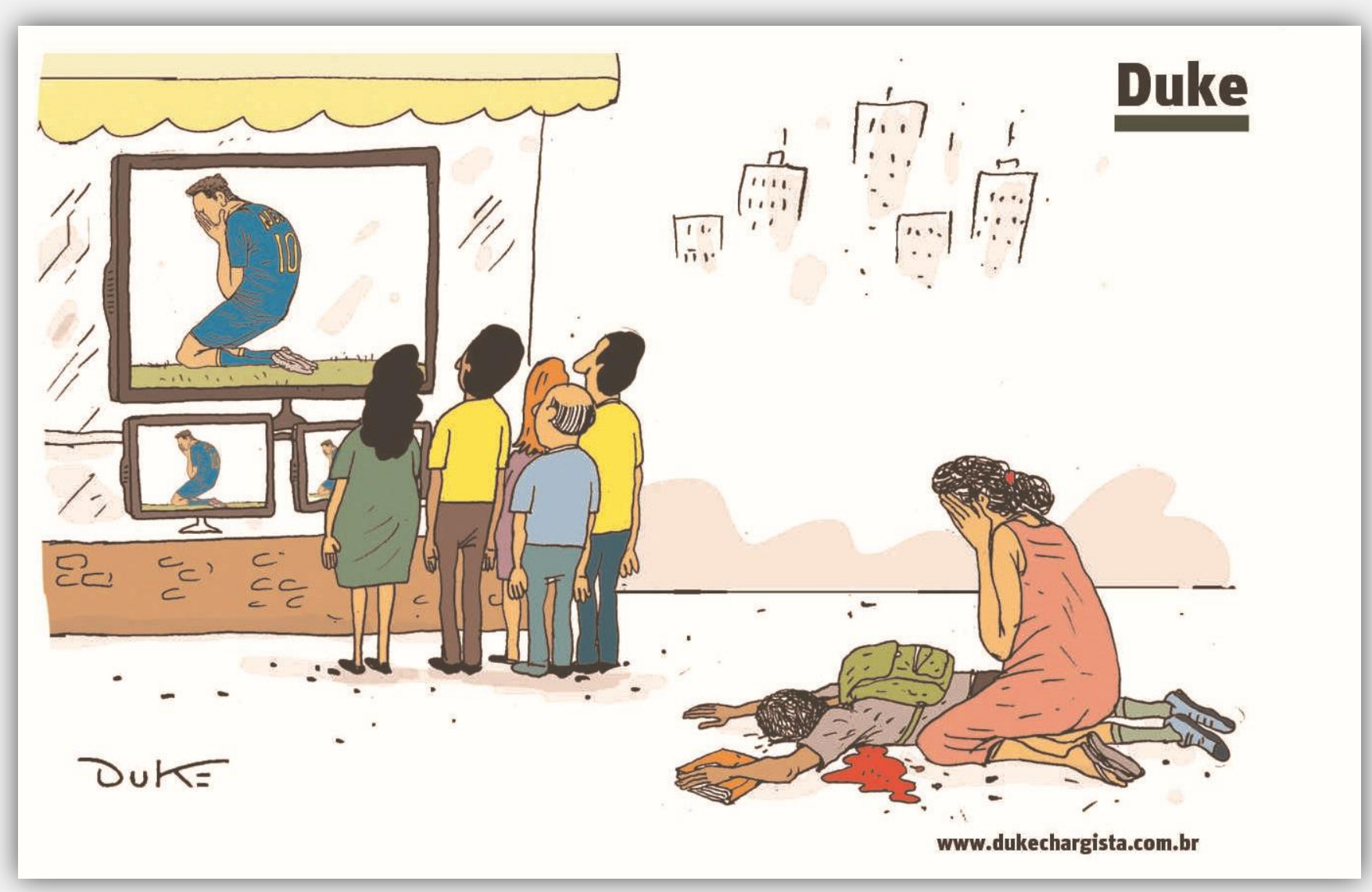

Jornal O Tempo, Domingo, 24 de junho de 2018. Capa da revista FuLiA / UFMG, v. 3, n. 2, 2018. 